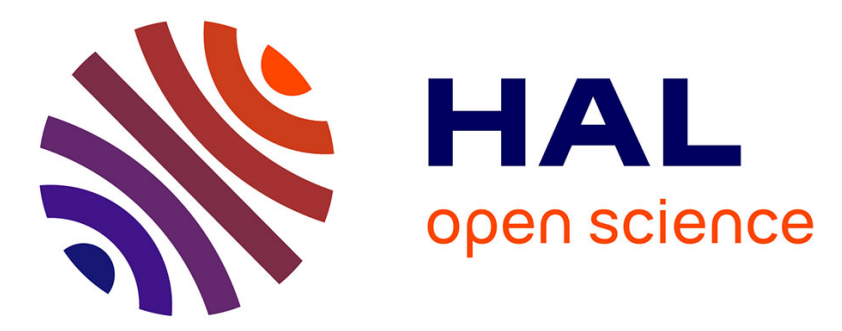

\title{
Researching Computers and Education Through Actor-Network Theory
}

\author{
Arthur Tatnall
}

\section{To cite this version:}

Arthur Tatnall. Researching Computers and Education Through Actor-Network Theory. 1st International Conference on Sustainable ICT, Education, and Learning (SUZA), Apr 2019, Zanzibar, Tanzania. pp.78-88, 10.1007/978-3-030-28764-1_10 . hal-02515737

\section{HAL Id: hal-02515737 \\ https://hal.inria.fr/hal-02515737}

Submitted on 23 Mar 2020

HAL is a multi-disciplinary open access archive for the deposit and dissemination of scientific research documents, whether they are published or not. The documents may come from teaching and research institutions in France or abroad, or from public or private research centers.
L'archive ouverte pluridisciplinaire HAL, est destinée au dépôt et à la diffusion de documents scientifiques de niveau recherche, publiés ou non, émanant des établissements d'enseignement et de recherche français ou étrangers, des laboratoires publics ou privés. 


\title{
Researching Computers and Education through Actor-Network Theory
}

\author{
Arthur Tatnall [0000-0003-4317-971X) \\ Victoria University, Melbourne, Australia \\ Arthur.Tatnall@vu.edu.au
}

\begin{abstract}
The teaching of information technology and education needs to keep up to date to remain relevant. With technology changing rapidly this is no easy task. It is even more important that research into this area be sustainable and to keep up to date. The use of, or teaching about, computers in education involves both humans - teachers, students and parents, and non-humans - technology. Research into computers and education is socio-technical as it has to deal with both human and non-human actors, and so actor-network theory (ANT) can provide a useful research approach. This paper outlines actor-network theory and Innovation Translation (informed by ANT) and provides some examples of research using ANT as a lens for analysis.
\end{abstract}

Keywords: Information technology, education, research, actor-network theory.

\section{Research in IT Education}

For teaching about, or use of information technology in education to remain relevant and sustainable, research must keep up to date as new technologies appear, old one disappear or are substantially changed, new approaches to making use of IT in education emerge, and students' experience IT differently.

Research can be regarded as "the systematic investigation and study of materials and sources to establish facts and reach new conclusions" [1]. Research in education, however, is not just the province of academics in Faculties of Education (although they are the ones who formalise it in academic papers!). Teachers need to research new technology: how it works and how it could be used in their classrooms. Students need to research their school work, Parents need to research which school to send their children, and education authorities need to research new technologies and teaching approaches. This paper is thus about much more than just academic research into computer education.

\section{Computers and Education}

Education is about people: students, teachers and parents. Computers are about technology. Research into the use of information technology in education is 
concerned with the ways people use, and learn about computer-based systems to make education better. It also has to deal with issues involving people and things: with both human and non-human entities [2]. Such research is thus truly socio-technical in nature. Researchers in this area need to deal with problems of how to handle complexities due to a multitude of interactions between people and computers [3]. It thus involves neither social nor technical determinism.

\section{Actor-Network Theory}

Social Determinism suggests that social interactions and constructs alone determine individual behaviour. On the other hand Technological Determinism assumes that a society's technology determines the development of its social structure and cultural values [4]. Clearly, as a study of the use of computers and education has elements that depend on people and others that depend on the technology, a simplistic view that it could be classed as either Social Determinism or Technological Determinism therefore cannot be valid.

Actor-Network Theory (ANT), or the 'sociology of translations' [5-7] is concerned with studying the mechanics of power that occurs through construction and maintenance of networks made up of both human and non-human actors. It was originally developed in the late 1980s by: Bruno Latour and Michael Callon (École Nationale Supérieure des Mines de Paris) and John Law (Lancaster University, UK).

In ANT an actor is seen as any human or non-human entity that is able to make its presence individually felt [8] by the other actors [9]. ANT deals with the socialtechnical divide by denying that purely technical or purely social relations are possible as nothing is purely social and nothing is purely technical [10].

Actor-network theory declares that the world is full of hybrid entities [11] containing both human and non-human elements. It was developed to analyse situations where separation of these elements is difficult [12]. You could ask, for example, which part of a software app is just an inanimate object and which is the result of human interactions. To differentiate a computer program's technical aspects from the influence exerted by the socio-cultural background of the software development team is quite difficult [13-15]. What part of a school class on geography that makes use of Google Maps is driven by the technology and which is due to the inclinations and approach of the teacher?

To address the need to treat both human and non-human actors fairly and in the same way, ANT is based upon three principles:

- Agnosticism - analytical impartiality towards all actors involved in the project, whether they are human or non-human.

- Generalised symmetry - explains conflicting viewpoints of different actors the same way for human and non-human actors.

- Free association - requires the abandonment of all a-priori distinctions between the technological and social $[6,16]$. 
In summary, ANT requires all human and non-human actors to be acknowledged and their interactions to be treated in the same way. It is their interactions that matter.

\section{$4 \quad$ Researching the Use of Computers and Education}

Several examples of the use of actor-network theory in educational research in which I have been involved are now described. ANT is not a research methodology as such and can best be described as a lens through which to analyse data, usually collected through the use of case studies, action research, and other qualitative methods.

\subsection{Factors Determining the Balance between Online and Face-to-Face Teaching: an Analysis using Actor-Network Theory}

Papers published by Wong and Tatnall [17, 18], based on Wong's PhD research, involved an investigation of approaches to teaching a first-year accounting subject at Victoria University. Wong had recently introduced some online teaching using Blackboard (previously known as WebCT) into her classes and wanted to understand how its use compared with that of face-to-face teaching: which the students preferred, and which was most educationally effective.

In this case a simple investigation quickly showed that a large number of different entities had an effect on determining how much online and how much face-to-face teaching to include in this subject, and that not all were human as the technology itself has an important determining effect [19]. This suggested an investigation through the lens of actor-network theory.

The first step in an actor-network analysis is to identify the actors involved. In this case these were:

- Human Actors: Bachelor of Business Course Coordinator; BAO-1101 Subject Coordinator, Lecturers, Tutors and (Contract) Tutors; other lecturers; Faculty Dean; Head of the School of Accounting, Students

- Non-Human: University Administration, Policy and Infrastructure; IT Services; Computers; computer laboratories; other e-learning technologies (including remote access) and the Blackboard e-learning environment itself.

Each of these human and non-human actors potentially influenced the balance between an online and a face-to-face approach.

One of the issues brought out by the ANT investigation was the effect that force of personality and presence has in a teaching and learning environment and how this contrasts with the effect of the technology. Many students believed that as well as use of the technology, the personal interactions of face-to-face added value to their learning experience [20].

\section{$5 \quad$ Technological Innovation and Education}

Much of the research in the use of information technology in education relates to how or whether new technologies are adopted. This can be described as research into 
technological innovation in education. While invention can be seen as discovery or creation of new ideas, innovation involves putting these ideas into practice [21].

There are several approaches to researching technological innovation the most commonly used being: Diffusion of Innovations (Rogers [22]), TAM: Technology Acceptance Model (Davis et al. [23]) and UTAUT: Unified Theory of Acceptance and Use of Technology (Venkatesh et al. [24]). In this paper, however, I will make use of another approach: Innovation Translation from Actor-Network Theory.

When an organisation (or individual) is considering use of a technological innovation they do not always want to adopt it in its entirety but are interested in only some aspects and not others. Innovation Translation [6], informed by actor-network theory, provides a useful means for investigating adoption or non-adoption of new technology. In ANT terms this technology needs to be translated [6] into a form that is more appropriate for the potential adopter so that the innovation finally adopted is often not in its original form, but a translation into a form that is suitable for their use [25].

Callon [6] outlines four aspects or 'moments' in the process of translation:

1. Problematisation - key actors attempt to define the nature of the problem and the roles of other actors so that they are seen as having the answer.

2. Interessement - processes that attempt to interest and impose the identities and roles defined in the problematisation on the other actors.

3. Enrolment - if the interessement is successful through a process of coercion, seduction or consent [26] adoption of this innovation will follow.

4. Mobilisation occurs as the proposed solution gains wider acceptance with some working to promote the technology to others.

\subsection{Adoption of Visual Basic in a University Curriculum}

This section looks at an example of using Actor-Network Theory to understand the process of information systems curriculum innovation.

The discipline of Information Systems (IS) involves investigation of how businesses, and other organisational entities, can make the best use of ICT to further their business aims [9]. I will argue that changes in IS curriculum can best be thought of as innovations and considered using innovation theory.

This section provides an actor-network account of how Visual Basic (VB) entered the information systems curriculum at Bourke University of Technology in Melbourne in the 1990s [27]. Even though this innovation adoption and curriculum change took place twenty years ago, similar processes, interactions and associations to those here described are likely to be found in any current curriculum innovation.

This story begins in the early 1990s at a time when two Colleges of Advanced Education: Wills Institute of Technology and Bourke Institute of Technology were merging to form Bourke University of Technology ${ }^{3}$ [27-29]. It will be considered in four parts.

3 All human and institutional names in this article are pseudonyms to preserve a degree of anonymity. 


\section{First attempts to use Visual Basic}

Not long after he began teaching at Wills Institute, Fred discovered Visual Basic for MS-DOS when undertaking an outside programming job. He liked the way that VB allowed a programmer to produce a prototype solution very quickly, with less bother than in other languages.

At Wills Institute, Fred had just started teaching an introductory IS subject that required use of a screen prototyping tool. Unfortunately Wills had no prototyping tools that could be used in the MS-DOS student labs and so this topic could not really be handled practically. Fred wondered if some screen design aspects of VB could do the job. He did this by selecting some features of VB while ignoring others. He could only use VB in this way by translating [6] it from a 'programming language and visual programming environment' into a 'screen prototyping tool'. The following year after the student labs had been equipped with new Windows PCs Fred decided to give VB a try in an Operating Systems Programming subject. This involved another translation of VB to become a 'language to teach Windows operating systems programming'. None of this would have been possible if not for the formation of a VB actor-network consisting of Fred, the introductory IS subject, the operating systems programming subject, Visual Basic, the student labs and the students. VB had now become firmly enrolled at Wills.

\section{Programming languages already in place at Bourke Institute}

At this time Bourke Institute of Technology used three programming languages in its teaching: Pick/BASIC, an assembly language system called Alice, and to a lesser extent COBOL (- not relevant to this discussion). This part of the story begins with seven actors: Bourke Institute of Technology, Pick/BASIC, Alice, COBOL, the IS curriculum and two humans: Stephen and James.

Starting our as a 'Working Man’s College', Bourke's mission had always been to provide an applied tertiary education, and to achieve this it made every effort to ensure that its curriculum was based on 'real' (meaning industry standard) approaches, applications and technologies.

At the time Pick which is a specialised database-oriented operating system that makes use of a programming language called Pick/BASIC [30-32] was very much industry standard and 'real' for some applications. Stephen then began assembling a network to assist Pick's entry into the IS curriculum. Pick could not have entered the IS curriculum unaided and needed to expand its network by addition of a local ally who was in a position to assist. This was Stephen, who decided to introduce Pick/BASIC to his students and quickly produced a powerful interessement to convince his colleagues. He describes how his students quickly adapted to Pick/BASIC, and were able to gain a very rapid understanding of the business problems he wanted them to consider.

In the late-1980s James, another Bourke lecturer was developing an introductory subject in computer architecture and operating systems. He decided to build a software simulator: 'Alice' to teach assembly language, so that with this 'virtual machine' students would be better able to understand what went on inside a computer. 
In terms of innovation translation, Stephen and James had thus each successfully problematised [6] a need for students to understand and use their respective approaches to programming.

\section{Entry of Visual Basic and the fate of the existing languages}

After the merger of Wills Institute and Bourke Institute it was necessary that the new enlarged Bourke University of Technology to have the appearance of a single university and so it was necessary to quickly merge the curricula for each degree at each campus. Negotiations about the new course continued over almost two-years until the final version was accredited.

While this was happening Visual Basic made its appearance in a new elective subject called Graphic User Interface (GUI) and Event-Driven Programming, giving it a toe-hold in the curriculum. When the new curriculum was finalised, it was agreed that the first and second programming subjects were to be taught using Pick/BASIC. The Alice virtual machine did not find a place in the new degree as knowledge of the inner workings of a computer had become largely irrelevant to IS students. This meant that the curriculum now contained Pick/BASIC and Visual Basic, but not Alice.

\section{How VB remained in the curriculum}

Debate on programming languages did not stop then however due to the entry of a new actor: Object-Oriented Programming. This might have destabilised or posed a threat to the existing networks [26]. If it had been unprepared to face this threat Visual Basic would probably have been displaced from at least one IS subject, but VB had always made use of objects in designing screens, and its whole programming approach was object-based. Also at about this time a new object-oriented version of VB became available. Visual Basic thus remained in the Bourke IS curriculum for some years.

\subsection{Failure of the Victorian Education Ultranet}

The Ultranet was a form of extranet released for use in Government Schools by the Victorian Education Department in 2010 as "a student centred electronic learning environment that supports high quality learning and teaching, connects students, teachers and parents and enables efficient knowledge transfer.” [33]. It was intended to support delivery of curriculum, online teaching and sharing of knowledge across all Victorian Government Schools. Although it seemed like a good idea the time with lots of possibilities to do worthwhile things, by late 2012 it was not being used to any great extent in most schools and was abandoned by the Government in June 2013 [34]. This is the story of the life and death of the Ultranet viewed through an ANT lens.

An important Ultranet goal was to improve communication between schools, teachers and parents. The Ultranet was based on use of what it called Spaces (mini websites) using icons to identify each space and provide Applications for use in that space. Each Space was classified by its accessibility to different users (students, teachers, parents and the public) into one of the following categories: 
- Me Spaces (private, and accessible only to the owner),

- We Spaces (shared with permission) and

- $\quad$ See Spaces (open, public access).

Any investigation of adoption of the Ultranet must consider its technical and its human components. It necessarily involves a socio-technical research approach and methods and so an investigation using ANT and Innovation Translation is appropriate. An innovation is of no value unless adopted, and it will only be adopted if adapted to fill a need - unless it is translated.

\section{Problematisation}

Research suggests that the intention, or problematisation, by the State Government for the Ultranet was to create a system to offer access to learning materials and to inform parents of their child's progress. Its problematisation was as " $a$ student-centred electronic learning environment that supports high quality learning and teaching, connects students, teachers and parents and enables efficient knowledge transfer." [33]. This generally seemed like a good idea, but some teachers saw this as unnecessary as they were already using other learning management systems such as Blackboard or Moodle. Others saw connecting in this way with parents as a threat.

\section{Interessement}

The next step was to convince teachers and parents about the value of using the Ultranet. This got off to a bad start when the Ultranet was launched at a 'student-free day' of professional development for all teachers in August 2010. Unfortunately this day turned into a disaster when the Ultranet crashed at 9am. When it was running later, many teachers experienced problems and reported it as running extremely slowly [35-37].

As an attempt to convince teachers of the Ultranet's value, each Education Department region appointed 'Ultranet Coaches' to visit local schools and promote Ultranet use, and each school was asked to appoint an Ultranet Champion known as a 'Lead User'. Many teachers, however, quickly became disenchanted with the Ultranet compared with other tools that were more easily adaptable. "My experiences of the Ultranet so far have given me the impression that it is restricted and basic. While I can definitely see the value in what they are trying to achieve, it saddens me that so much funding and resources are being pumped into a clunky system in its infancy." [38]

The State Government and Education Departments' attempts at interessement had clearly been unsuccessful.

\section{Enrolment and Mobilisation}

If all had been well, enrolment would have followed, but given the failure of interessement very few schools did became enrolled and an even smaller number became mobilised and attempted to convince others. The Ultranet was abandoned by the Government in June 2013. 


\subsection{The Internet of Things and how it may relate to education}

The Internet of Things (IoT) involves connections of physical Things to the Internet and so is about inter-relationships between Things, or Non-Humans actors. The NonHuman actors, of course, cannot (yet) act alone and so we must also consider their interactions with Human Actors. In this socio-technical situation the use of ActorNetwork Theory to frame the discussion is most appropriate [39, 40].

Use of the IoT brings up the concept of machine (or Thing) independence. Independence can be defined as: "Free from outside control; not subject to another's authority" and "Capable of acting or thinking for oneself" [41]. Another definition adds: "Not subject to control by others" [42]. Over the next few years the Things, with the assistance of advances in artificial intelligence, will begin to develop identities and virtual personalities. In the past non-human actors have only been there to serve and to interact with humans but with the IoT will this still the case? We can question where this leaves humans, will the things take over? Speaking of artificial intelligence in a BBC broadcast in 2014 [43] Stephen Hawking suggested that: "The development of full artificial intelligence could spell the end of the human race" and "It would take off on its own, and re-design itself at an ever increasing rate. Humans, who are limited by slow biological evolution, couldn't compete, and would be superseded." [43]

There are many possible uses of the IoT and these are likely to increase over the next few years. One important use is that of RFID in healthcare. Hospitals need to keep track of equipment such as trolleys, surgical equipment, wheelchairs, infusion pumps and defibrillators and RFID can assist with this [44]. Driverless smart trains, driverless trucks and driverless cars, making use of the IoT, are also in use today. With the IoT, control of appliances such as heaters, air conditioners, washing machines, dishwashers, refrigerators, ovens and home alarms can be done from a distance by the human owner with the aid of a smart phone.

Although not fully explored as yet education is not exempt from the impact of the IoT. This is a developing area and much more research needs to be done in its development. Some possibilities, though, are clear. In school management, RFID readers could be installed at the school gate, the library, and other places to identify the movements of students who carry an electronic tag. A noise sensor could be used to inform a neighbouring classroom that their noise has exceeded a certain level. IoT can potentially play a role in monitoring student emotional states and classroom environments, especially in relation to students with special needs [45]. Another possible use of the IoT in education is in science laboratories where it could be used as a tool for conducting experiments without the presence of the actual equipment [46].

As well as making use of the IoT in education though, an important consideration is curriculum development and what should be taught to students at all levels about the IoT [47].

It must be stressed that there is much more to be considered and researched in relation to the IoT and education. The possibilities are both very attractive and potentially rather frightening. 


\section{The Internet of Things and other possibilities}

Not all IoT devices are serious in their application though and Amanda Davis [48] describes a video camera system that streams to your mobile phone to let you keep an eye on your cat while you are away. You can also talk to it through a two-way audio system and activate a moving laser pointer for your cat to chase to keep it amused until you come home.

In an article called: 'Do objects dream of an internet of things', Teodor Mitew [49] describes Brad the Toaster:

"Brad is a toaster connected to the internet, and to other toasters like him. He often exchanges information with his fellow toasters, with whom he tweets about the usage habits of their human hosts. He and his fellow toasters are not owned as other, simpler, toasters before them used to be. They are hosted by humans who have promised to use them. He loves being used, and is sensitive to learning that other toasters are used more often than him. When feeling underappreciated, Brad will draw attention to himself by playing pranks, throwing tantrums, and expressing his sadness loudly on Twitter. Eventually, Brad will become disillusioned and demand a move to another, more caring host. He will depart, leaving the smell of burned toast behind him.” [49:4]

\section{Conclusion}

Research into computers in education is very important, but must be sustainable and kept up to date as new technologies and new approaches to teaching appear and changes in society result. This research must be socio-technical as it needs to investigate actions and interactions between teachers, students, parents, education authorities and the technology itself: to actions and interactions between humans and non-humans. In this paper I have argued that using the lens of actor-network theory and innovation translation can provide a useful research approach.

\section{References}

1. Collins English Dictionary. Definition of 'research'. 2018 December 2018]; from: https://www.collinsdictionary.com/us/dictionary/english/research.

2. Tatnall, A., Actor-Network Theory as a Socio-Technical Approach to Information Systems Research, in Socio-Technical and Human Cognition Elements of Information Systems, S. Clarke, et al., Editors. 2003, Information Science Publishing: Hershey, PA. p. 266-283.

3. Tatnall, A., Actor-Network Theory Applied to Information Systems Research, in Encyclopedia of Information Science and Technology (2nd edition), $\mathrm{M}$. Khosrow-Pour, Editor. 2009, Information Science Reference: Hershey, PA. p. 20-24. 
4. Wikipedia. Social and Technological Determinism. 2018 December 2018]; Available from: https://en.wikipedia.org/wiki/Technological_determinism, https://en.wikipedia.org/wiki/Social_determinism.

5. Latour, B., The Powers of Association, in Power, Action and Belief. A New Sociology of Knowledge? Sociological Review monograph 32, J. Law, Editor. 1986, Routledge \& Kegan Paul: London. p. 264-280.

6. Callon, M., Some Elements of a Sociology of Translation: Domestication of the Scallops and the Fishermen of St Brieuc Bay, in Power, Action \& Belief. A New Sociology of Knowledge?, J. Law, Editor. 1986, Routledge \& Kegan Paul: London. p. 196-229.

7. Law, J., The Heterogeneity of Texts, in Mapping the Dynamics of Science and Technology, M. Callon, J. Law, and A. Rip, Editors. 1986, Macmillan Press: UK. p. 67-83.

8. Law, J., Technology and Heterogeneous Engineering: The Case of Portuguese Expansion, in The Social Construction of Technological Systems: New Directions in the Sociology and History of Technology, W.E. Bijker, T.P. Hughes, and T.J. Pinch, Editors. 1987, MIT Press: Cambridge, Ma. p. 111-134.

9. Tatnall, A., Using Actor-Network Theory to Understand the Process of Information Systems Curriculum Innovation. Education and Information Technologies, 2010. 15 (4 - Special Issue on Information Systems Curriculum): p. 239-254.

10. Law, J., ed. A Sociology of Monsters. Essays on Power, Technology and Domination. 1991, Routledge: London.

11. Latour, B., We Have Never Been Modern. 1993, Cambridge, MA: Harvester University Press.

12. Callon, M., Society in the Making: The Study of Technology as a Tool for Sociological Analysis, in The Social Construction of Technological Systems, W.E. Bijker, T.P. Hughes, and T.P. Pinch, Editors. 1987, The MIT Press: Cambridge, Ma. p. 85-103.

13. Tatnall, A. and Gilding, A. Actor-Network Theory and Information Systems Research. in 10th Australasian Conference on Information Systems (ACIS). 1999. Wellington: Victoria University of Wellington.

14. Cusumano, M.A. and Selby, R.W., How Microsoft Builds Software. Communications of the ACM, 1997. 40(6): p. 53-61.

15. Sahay, S., Implementation of Information Technology: A Space-Time Perspective. Organization Studies, 1997. 18(2): p. 229-260.

16. Singleton, V. and Michael, M., Actor-Networks and Ambivalence: General Practitioners in the UK Cervical Screening Programme. Social Studies of Science, 1993. 23(2): p. 227-264.

17. Wong, L. and Tatnall, A., Factors Determining the Balance between Online and Face-to-Face Teaching: an Analysis using Actor-Network Theory. Interdisciplinary Journal of Information, Knowledge and Management, 2010. 5: p. 167-176. 
18. Wong, L. and Tatnall, A., The Need to Balance the Blend: Online versus Faceto-Face Teaching in an Introductory Accounting Subject. Journal of Issues in Informing Science and Information Technology (IISIT), 2009. 6: p. 309-322.

19. Tummons, J., Higher Education in Further Education in England: An ActorNetwork Ethnography. International Journal of Actor-Network Theory and Technological Innovation, 2009. 1(3): p. 55-69.

20. Wong, L., The E-Learning Experience - Its Impact on Student Engagement and Learning Outcomes, in Business \& Economics Society International Conference. 2010: Bahamas.

21. Maguire, C., Kazlauskas, E.J., and Weir, A.D., Information Services for Innovative Organizations. 1994, Sandiego, CA.: Academic Press.

22. Rogers, E.M., Diffusion of Innovations. 5th ed. 2003, New York: The Free Press.

23. Davis, F., Perceived Usefulness, Perceived Ease of Use, and User Acceptance of Information Technology. MIS Quarterly, 1989. 13(3): p. 318-340.

24. Venkatesh, V., Morris, M.G., Davis, G.B., and Davis, F.D., User Acceptance of Information Technology: Toward a Unified View. MIS Quarterly, 2003. 27(3): p. 425-478.

25. Tatnall, A., Information Systems, Technology Adoption and Innovation Translation. International Journal of Actor-Network Theory and Technological Innovation, 2009. 1(1): p. 59-74.

26. Grint, K. and Woolgar, S., The Machine at Work - Technology, Work and Organisation. 1997, Cambridge: Polity Press. 199.

27. Tatnall, A., Innovation and Change in the Information Systems Curriculum of an Australian University: a Socio-Technical Perspective. 2000, Central Queensland University: Rockhampton.

28. Tatnall, A. and Davey, W. How Visual Basic Entered the Curriculum at an Australian University: An Account Informed by Innovation Translation. in Challenges to Informing Clients: A Transdisciplinary Approach (Informing Science 2001). 2001. Krakow, Poland: Informing Science

29. Tatnall, A., Innovation Translation in a University Curriculum. 2007, Melbourne: Heidelberg Press.

30. Johnson, W. Pick, Universe, Unidata Resources. 2009 [cited 2010; Available from: http://knol.google.com/k/pick-universe-unidata-resources\#.

31. Pick Systems, The Pick Systems Approach: Now more than ever. 1998, Pick Systems: http://www.picksys.com/company/approach.html, 22 September 1998.

32. Pick Systems, An Incomplete History of Pick/BASIC. 1998, Pick Systems: http://www.picksys.com/articles/pw/119407.html, 22 September 1998.

33. Department of Education and Early Childhood Development. Ultranet. 2011 January 2012]; Available from: http://www.education.vic.gov.au/about /directions/ultranet/default.htm.

34. Tatnall, A. and Davey, W., Birth, Life and Death of the Victorian Education Ultranet. Education and Information Technologies, 2018. 23(4): p. 1585-1605.

35. Levy, M., 'Massive fail': technical glitches upset Ultranet training day, in The Age. 2010, The Age: Melbourne. 
36. Topsfield, J., Rollout of Ultranet Postponed, in The Age. 2010, Fairfax: Melbourne. p. 5.

37. Holden, S., Ultranet crashes. Teacher, 2010(214): p. 5-8.

38. ReflectiveTeacher, Unlimited Potential ... Unfortunate Ultranet. 2012: Melbourne.

39. Tatnall, A. and Davey, B., The Internet of Things and Beyond: Rise of the NonHuman Actors. International Journal of Actor-Network Theory and Technological Innovation, 2015. 7(4): p. 58-69.

40. Tatnall, A. and Davey, B., Towards Machine Independence: from Mechanically Programmed Devices to the Internet of Things, in International Histories of Innovation and Invention, A. Tatnall and C. Leslie, Editors. 2016, Springer International Publishing: Switzerland. p. 87-100.

41. Oxford, The Concise Oxford English Dictionary. 11th edition ed, ed. C. Soanes and A. Stevenson. 2004, Oxford: Oxford University Press.

42. Merriam-Webster. Merriam-Webster Dictionary. 2015 January 2016]; Available from: http://www.merriam-webster.com/dictionary/independent.

43. Cellan-Jones, R. Stephen Hawking warns artificial intelligence could end mankind. 2014 October 2015]; 2 December 2014:[Available from: http://www.bbc.com/news/technology-30290540.

44. Unnithan, C., Examining Innovation Translation of RFID Technology in Australian Hospitals through a Lens Informed by Actor-Network Theory, in Information Systems. 2014, Victoria University: Melbourne, Australia.

45. Kassab, M., DeFranco, J.F., and Voas, J., “Smarter” Education. IT Professional (IEEE Computer Society), 2018(September/October): p. 20-24.

46. Muhammad, A.H., Nur Dalila, K.A., Zakiah, M.Y., Amar, F., and Nooritawati, M.T., Computer Assisted E-Laboratory using LabVIEW and Internet-of-Things Platform as Teaching Aids in the Industrial Instrumentation Course International Journal of Online Engineering, 2018. 14(12).

47. Voas, J. and Laplante, P., Curriculum Considerations for the Internet of Things. COMPUTER (IEEE Computer Society), 2017(January): p. 72-75.

48. Davis, A. Boost Your Home's IQ With These Seven Gadgets. 2015 January 2016]; Available from: http://theinstitute.ieee.org/technology-focus/technologytopic/boosting-your-homes-iq-with-these-seven-gadgets.

49. Mitew, T., Do objects dream of an internet of things? . The Fibreculture Journal, 2014. 2014(23): p. 1-25. 